\title{
ジエチルジチオカルバミン酸銅を指示薬 とする微量シアンイオンの容量分析法
}

\author{
田中 善正，山本 セツ*
}

\begin{abstract}
シェチルジチオカルバミン酸銅の四塩化炭素溶液を指示薬として微量のシアンイオンを硝酸第二氷銀 溶液で滴定する方法を考案した。すなわち滴定の途中は滴加した水銀イオンはシアンイオンと結合して 指示薬と反応しないが，すべてのシアンイオンがシアン水銀となる量以上に硝酸水銀を滴加すると指示 薬と水銀イオンが反応して指示薬溶液の脱色が起り終点を知るてとができた。本法によれば $0.0001 M$ 硝酸第二水銀溶液を用い 30〜140 ケのシアン化カリウムが簡易かつ正確に定量できた。 ハロゲンイオン 扣上び有機物は本定量法を障害したが，試料を酒石酸酸性となし蒸留した留液について本法を試み障害 なくシアンイオンを定量するととができた。
\end{abstract}

\section{1 緒䓂}

著者らはさきにジェチルジチオカルバミン酸銅の四塩 化炭素溶液が微量の水銀イオンによって脱色される反応 を用いて，微量の水銀イオンをジエチルジチオカルバミ ン酸銅の四塩化炭素溶液で滴定する方法を報告した1).

この報告でも述べたように本定量法は臭素, ヨウ素, 硫シアン, シアンなどのイオンの共存では滴定值に誤差 を生じ，ことにシアンイオンの共存ではいちじるしく滴 定值の減少をきたした.すなわちシアン水銀はジェチル ジチオカルバミン酸銅と全然反応しないので，水銀の定 量にシアンイオンを添加すればシアン水銀となった分だ け滴定值が減少した。 そこで逆にこの反応を用いてシア ンイオンの定量ができるのではないかと考光て実験をお こない満足すべき結果が得られたのでここに報告する. 本定量法の骨子はジェチルジチオカルバミン酸銅の四塩 化炭素溶液を指示薬としてシアンイオンを $0.0001 M$ 硝 酸第二水銀溶液で滴定するものであの て, 滴定の途中で は滴加した水銀イオンはすべてシアン水銀となり指示薬 とは反応せず四塩化炭素層は褐色を保ったが，存在した シアンイオンが全部シアン水銀となる量以上に硝酸第二 水銀溶液を滴加すると, 過剩の水銀イオンは指示薬と反 応して四塭化炭素層の退色が始まった。ささらに滴加をつ づけ四塩化炭素層が完全に脱色するまでに要した $\mathrm{m} l$ 数 をよみ,この值からあらかでめ測定しておいた指示薬ブ ランクすなわち指示薬溶液を脱色するのに要する硝酸水 銀溶液の $\mathrm{m} l$ 数を差し引けば, 残りはシアンイオンに対 応する硝酸第二水銀溶液の量となり，簡易に微量のシア ンイオンを定量することができた。

$*$ 熊本大学薬学部 $:$ 熊本市大江町九品寺
2 試薬溶液

$0.0001 M$ ジエチルジチオカルバうン酸銅溶液（以下 指示薬溶液と略称する)： ジエチルジチオカルバミン酸 銅約 $18 \mathrm{mg}$ を四塩化炭素 $500 \mathrm{~m} l$ に溶解してつくり褐 色瓶中に貯えた. この溶液の指示薬ブランクの測定に は, この $5 \mathrm{~m} l$ を正確に分液口ートに取り蒸留水約 $20 \mathrm{ml}$ を加え, 次項で述べる $0.0001 M$ 硝酸第二水銀溶液をビ ェレットから少量ずつ滴加してょく振りまぜ, 四塩化炭 素層が完全に脱色するまでに要する硝酸第二水銀溶液の 量をはかり,この 5 分の 1 をって指示薬溶液 $1 \mathrm{~m} l$ に対 応する $0.0001 M$ 硝酸第二水銀溶液の量とした.この指 示薬ブランクの值は指示薬溶液を褐色瓶中に保存しても 徐々に変化したので， 1 週間ごとに測定しなおした。

$0.05 M$ 硝酸第二水銀溶液 : 硝酸第二水銀 $\mathrm{Hg}\left(\mathrm{NO}_{3}\right)_{2}$. $1 / 2 \mathrm{H}_{2} \mathrm{O}$ 約 $16.7 \mathrm{~g}$ に濃硝酸約 $60 \mathrm{ml}$ を加え蒸留水で希 釈して全量を $1000 \mathrm{~m} l$ となし概略 $0.05 M$ 溶液を調製 し，これを常法にしたがって硫酸第二鉄アンモニウムを 指示薬として硫シアン化アンモニウム標準液で滴定し正 確な力価を決定した。本溶液は保存用の原液であって褐 色瓶中に貯えた.

$0.0001 . M$ 硝酸第二水銀溶液 : 上記 $0.05 M$ 硝酸第二 水銀溶液 $2 \mathrm{~m} l$ を正確に取り蒸留水を加えて全量を 1000 $\mathrm{m} l$ とした。本溶液を滴定に用いたのであるが，この調 製は必ず使用当日おこなった。

\section{3 直接法による定量法}

\section{$3 \cdot 1$ 滴定方法および定贵結果}

あらかじめ少量の水を入れた分液口一トに試料溶液の 適当量を正確に取り, 指示薬溶液 $1 \mathrm{~m} l$ を正確に加え, 
ビュレットから $0.0001 M$ 硝酸第二水銀溶液を滴加して よく振りまぜた。四塩化炭素層の褐色が退色し始めれば 注意して 1 滴ずつ硝酸水銀溶液を滴加して振りまぜ，四 塩化炭素層が完全に脱色するまで滴定をつづけた．この 時までに要した硝酸第二水銀溶液の量から指示薬ブラン クの值を差し引いた $\mathrm{m} l$ 数をもってシアンイオンに対応 する硝酸第二水銀溶液の量とした. 計算は 1 モルの硝酸 第二水銀が 2 モルのシアン化カリウムに対応する.した がって

\section{$0.0001 M \mathrm{Hg}\left(\mathrm{NO}_{3}\right)_{2} 1 \mathrm{ml}=13.022 \gamma \mathrm{KCN}$}

として計算した. 本滴定法の正確度を検するため含量既 知のシアン化カリウム溶液の一定量を取って上記方法に したがって定量した. シアン化カリウム溶液注概略 0.02 $M$ の溶液をつくり, Liebig 法によって正確な含量を決 定したのち炭酸不含の蒸留水で希釈したものを用いた。

定量結果は Table I に示したように 30〜140 rのシア ン化カリウムに対し最大 $1.3 \gamma$, 平均 $0.4 \gamma$ の誤差で滴 定することができた。

Table I Determination of $\mathrm{KCN}$

\begin{tabular}{|c|c|c|c|}
\hline $\begin{array}{c}\mathrm{KCN} \text { taken } \\
(\gamma)\end{array}$ & $0.0001 M \underset{(\mathrm{m} l) .}{\mathrm{Hg}\left(\mathrm{NO}_{3}\right)_{2}}$ & $\begin{array}{l}\mathrm{KCN} \text { found } \\
(\gamma)\end{array}$ & $\begin{array}{c}\text { Error } \\
(\gamma)\end{array}$ \\
\hline 28.8 & 2.24 & 29.1 & +0.3 \\
\hline$" \prime$ & 2.20 & 28.7 & -0.1 \\
\hline$" \prime$ & 2.19 & 28.5 & -0.3 \\
\hline 43.2 & 3.25 & 42.3 & -0.9 \\
\hline$" \prime$ & 3.32 & 43.2 & 0 \\
\hline$" 1$ & 3.33 & 43.3 & +0.1 \\
\hline 57.6 & 4.35 & 56.8 & -0.8 \\
\hline$"$ & 4.46 & 58.0 & +0.4 \\
\hline "I & 4.43 & 57.7 & +0.1 \\
\hline 72.0 & 5.56 & 72.4 & +0.4 \\
\hline "I & 5.52 & 71.9 & -0.1 \\
\hline "I & 5.52 & 71.9 & -0.1 \\
\hline 100.5 & 7.62 & 99.2 & -1.3 \\
\hline " & 7.69 & 100.1 & -0.4 \\
\hline$" 1$ & 7.75 & 100.9 & +0.4 \\
\hline 143.5 & 10.96 & 142.7 & -0.8 \\
\hline " & 11.03 & 143.6 & +0.1 \\
\hline " & 10.98 & 143.0 & -0.5 \\
\hline
\end{tabular}

\section{$3 \cdot 2$ 共存イオンの影響}

以上述べたように本定量法は微量のシアンイオンを簡 易かつ正確に定量できるが，ハロゲンイオンの共存では 滴定にいちじるしい誤差を生じた.たとえば 140.8 rの シアン化カリウムを取り, 各種濃度の塩化ナトリウム溶 液を添加して 3.1 の方法でシアンイオンを定量した結果 を Table II に示す.
Table II Determination of $\mathrm{KCN}$ in the presence of $\mathrm{NaCl}$

\begin{tabular}{ccccc}
\hline \hline \multirow{2}{*}{$\mathrm{NaCl}$ added } & $\begin{array}{c}0.0001 \mathrm{M} \mathrm{Hg}\left(\mathrm{NO}_{3}\right)_{2} \\
(\mathrm{ml})\end{array}$ & $\begin{array}{c}\mathrm{KCN} \text { found } \\
(\gamma)\end{array}$ & $\begin{array}{c}\text { Error } \\
(\gamma)\end{array}$ \\
\hline \multicolumn{2}{c}{0} & 10.81 & 140.8 & 0 \\
$0.0001 N$ & $1 \mathrm{ml}$ & 9.01 & 117.3 & 23.5 \\
$\prime \prime$ & 5 & 8.07 & 105.1 & 35.7 \\
$0.001 N$ & 1 & 7.30 & 95.1 & 45.7 \\
$\prime \prime$ & 5 & 6.81 & 88.7 & 52.1 \\
$0.01 N$ & 1 & 4.42 & 57.6 & 83.2 \\
$\prime \prime$ & 2 & 4.03 & 52.5 & 88.3 \\
\hline
\end{tabular}

\section{4 蒸留法による定量法}

直接法による定量はごく限られた試料にしか応用でき ず, 著者らが目的としている裁判化学的な試料のように 多量の有機物および塩化物の共存する場合には用いるこ とができない.とこで著者はまずシアン化水素を水蒸気 蒸留で留出させ, この留液について前記定量方法を試み 妨害物質の影響を受けることなくシアンイオンを定量す ることができた。

\section{$4 \cdot 1$ 蒸留方法および定量結果}

内容約 $100 \mathrm{ml}$ の丸底コルベンに試料を取り $5 \%$ 酒石 酸溶液 $10 \mathrm{ml}$ を加え水で希釈して全量約 $50 \mathrm{ml}$ となし, 水浴中で加熱しつつこれに $30 \%$ 水酸化カリウム溶液を 通じて炭酸ガスを除去した空気を導入した. シアン化水 素は水蒸気および空気とともに留出するからリービッヒ の泠却器を径て三角フラスコの受器に導いた. 受器には あらかじめ $10 \%$ の水酸化ナトリウム溶液 $1 \mathrm{ml}$ を蒸留 水 $15 \mathrm{ml}$ で希釈したものを入れ, 冷却器の末端に接続し たガラス管をこの液中に浸した. 空気を徐々に通じなが ら約 15 分加熱するとシアン化水素は完全に留出するの で, 受器をはずし, $\gamma$-ジニトロフェノール $(0.1 \%$ アル コール溶液) 数滴を加え, 指示薬の黄色がほとえど退色 するまで希硫酸を加えて中和したのち，3・1 の方法にし たがってシアンイオンを定量した．中和の際最初はブロ ムフェノールブルーを用いたが，これは滴定の際指示薬 の酸性色が四塩化炭素層に反映して終点の判定が困難で あり, また水層と四塩化炭素層との境界に着色の浮遊物 を生じたのでその使用を中止した・ $\gamma$-ジニトロフェノー ルを用い上記の条件で滴定すればその酸性色は無色であ ってなんら障害が起らなかった。

また中和に用いる酸は必ず硫酸であることが必要で, もし塩酸や硝酸を用いると滴定值は理論値よりも小さく なった・含量既知のシアン化カリウム溶液を用い蒸留法 にしたがって定量した結果は Table III に示したよう 
に、シアン化カリウム $30 〜 140 \gamma$ においてほとえど完全 に留出し定量しうることが判明した。

Table III Determination of $\mathrm{KCN}$ after distillation

\begin{tabular}{cccc}
\hline $\begin{array}{c}\mathrm{KCN} \text { taken } \\
(\gamma)\end{array}$ & $0.0001 \mathrm{M} \mathrm{Hg}\left(\mathrm{NO}_{3}\right)_{2}$ & $\begin{array}{c}\mathrm{KCN} \text { found } \\
(\gamma)\end{array}$ & $\begin{array}{c}\text { Error } \\
(\gamma)\end{array}$ \\
\hline 28.3 & 2.20 & 28.6 & +0.3 \\
$\prime \prime$ & 2.17 & 28.3 & 0 \\
70.8 & 5.42 & 70.6 & -0.2 \\
$\prime \prime$ & 5.32 & 70.1 & -0.7 \\
100.5 & 7.67 & 99.9 & -0.6 \\
$\prime \prime$ & 7.70 & 100.3 & -0.2 \\
143.5 & 11.00 & 143.2 & -0.3 \\
$\prime \prime$ & 10.97 & 142.9 & -0.6 \\
\hline
\end{tabular}

\section{$4 \cdot 2$ 食品中に混入したシアン化カリゥムの定量}

Table III の実験は単純なシアン化カリウム溶液につ いておこなったものであるが，さらに本定量法が裁判化 学的な試料に応用できるかどうか学検討するため, 食パ

Table IV Determination of $\mathrm{KCN}$ in bread after distillation

\begin{tabular}{cccc}
\hline $\begin{array}{c}\mathrm{KCN} \text { taken } \\
(\gamma)\end{array}$ & $0.0001 M \underset{(\mathrm{m} l)}{\mathrm{Hg}\left(\mathrm{NO}_{3}\right)_{2}}$ & $\begin{array}{c}\mathrm{KCN} \text { found } \\
(\gamma)\end{array}$ & $\begin{array}{c}\text { Error } \\
(\gamma)\end{array}$ \\
\hline 72.0 & 5.50 & 71.6 & -0.4 \\
$\prime \prime$ & 5.48 & 71.4 & -0.6 \\
138.0 & 10.54 & 137.3 & -0.7 \\
\hline
\end{tabular}

ン $2 \mathrm{~g}$ にシアン化カリウムを添加したものについて4・1の 方法にしたがって定量を掞こなった。その結果は Table IV に示古.

実験值は理論值よりやや低く出る傾向があるが，本定 量法は十分実用分析として用い得ることが判明した. 食 パンを $5 \mathrm{~g}$ に増量した時は液量 $50 \mathrm{ml}$ ではコルベンの. 内容物が固化して蒸留を妨げ実験值は理論值より低くな った.

\section{交献}

1) 田中善正，山本セツ：本誌，5，440 (1956). is

Volumetric determination of cyanide using cupric diethyldithiocarbamate as an indicator. Yoshimasa TanaKa and Setsu Yamamoto (Faculty of Pharmacy, University of Kumamoto)

A new volumetric determination of micro quantities of cyanide has been investigated. A sample solution containing cyanide ions can be titrated by $0.0001 M$ mercuric nitrate solution with carbon tetrachloride solution of cupric diethyldithiocarbamate as an indicator. At the end point, the brown coloration of carbon tetrachloride layer disappears. The quantitative determination of $30 \sim 140 \gamma$ of potassium cyanide can be made within an error of $\pm 1.3 \gamma$. The presence of halide or organic matter causes an error, but after the steam distillation cyanide can be determined without any disturbance.

(Received June 18, 1959)

\section{ジフェニルカルバチッド水銀紙を用いる 微量シアンイオンの検出および定量}

田中 善正，山本 セツ*

青紫色のジフェニルカルバチッド水銀紙は中性ないしアルカリ性でシアンイオンによって赤色虽す る. 試料觉ミクロガス発生器にとり重炭酸ナトリウムを加えて加熱し, 発生するガス觉水酸化ナトリウ ム溶液で湿した試験紙に接触させると，シアンイオンの存在で試験紙が赤変し $0.05 \gamma$ のシアンイオン まで検出するてとができた．硫化物は類似の反応を呈するが硝酸力ドミウムを加えるとその障害が除去 できた。またての試験紙の変色した部分の長さはシアンイオンの量に比例し，その長さをはかることに より簡易に 1〜10 rのシアンイオンを定量するととができた. 本定量法は硫化物，フェリシァン化物， ヨウ化物の共存で誤差を生じたが前二者は硝酸カドミウムの添加によって後者は蒸留によって障害觉除 くことができた。また本法は裁判化学的な試料についても実施することができた。 